\title{
NEW TENDENCIES IN WINE TOURISM IN TOKAJ WINE REGION (HUNGARY): THE DECREASING ROLE OF TOKAJI ASZÚ AS A DOMINANT BRAND
}

\author{
Nikolett DROTÁR \\ University of Debrecen, Faculty of Science and Technology, Department of Social Geography and \\ Regional Development Planning, Egyetem tér 1, 4032 Debrecen, Hungary, e-mail: drotar.nikolett0411@gmail.com
}

Gábor KOZMA*

University of Debrecen, Faculty of Science and Technology, Department of Social Geography and

Regional Development Planning, Egyetem tér 1, 4032 Debrecen, Hungary, e-mail: kozma.gabor@ science.unideb.hu

\begin{abstract}
Citation: Drotár, N., \& Kozma, G. (2021). NEW TENDENCIES IN WINE TOURISM IN TOKAJ WINE REGION (HUNGARY): THE DECREASING ROLE OF TOKAJI ASZÚ AS A DOMINANT BRAND. GeoJournal of Tourism and Geosites, 34(1), 197-201. https://doi.org/10.30892/gtg.34126-637
\end{abstract}

\begin{abstract}
The aim of paper is to explore the economic, social and political changes in Tokaj Wine Region (Hungary) in last 30 years and present their consequences on wine tourism. We analysed the data regarding European Union grant application of economic enterprises a nd we conducted personal interviews with the leaders of some of the major wineries of the region. Among significant changes which have taken place in Tokaj Wine Region since 1990s the following have to be mentioned: change in ownership of wineries, the evolution in the technology of winemaking, the new activity of state government and local authorities, the increase in the number of wine varieties produced and European Union financial support. Wine tourism in the region has undergone significant changes (increase role of smaller wineries and wine varieties). Settlements on the western side of the region are becoming increasingly important.
\end{abstract}

Key words: wine tourism, Hungary, Tokaj Wine Region, European Union, geographical shift

\section{INTRODUCTION}

The Tokaj Wine Region (according to surveys, the $2^{\text {nd }}$ most popular wine region in Hungary - Hlédik and Harsány, 2019), which is situated in the north-eastern part of the country, on the eastern and southern sides of the Zemplén Mountains (Figure 1), plays a prominent role among Hungarian wine regions. The uniqueness and key role of the area is well illustrated by the fact that in 2002, on the basis of the decision of the UNESCO World Heritage Committee, it was added to the list of World Heritage sites under the name "Tokaj Wine Region Historic Cultural Landscape". In contrast with most other wine regions in Hungary, the main products of the Tokaj wine region are white wines, including the world-famous Tokaji Aszú, which is considered as one of the most important attractions of the region's wine economy.

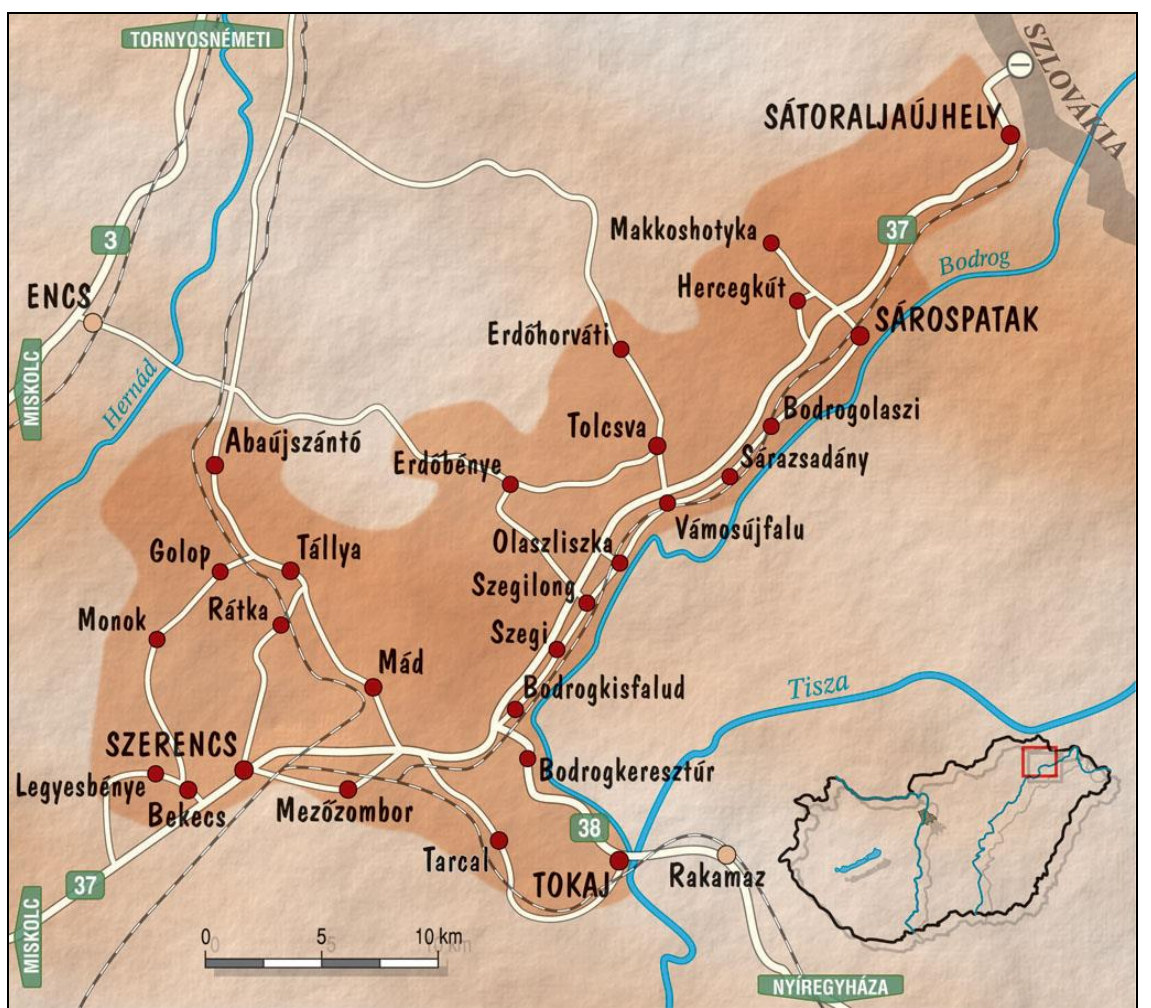

Figure 1. Location of Tokaj Wine Region in Hungary and its settlements (Source: own cartographical work)
In recent decades, however, there have been significant changes in the region in several respects, which have had momentous consequences. Our aim is to explore these changes and the factors behind them. The present paper fundamentally consists of three larger units. After reviewing the literature on wine tourism, we outline the most important elements of the pre-1990 development of the area. The third major unit deals with changes after 1990, paying particular attention to their impact on wine tourism.

\section{LITERATURE REVIEW}

In recent decades, wine tourism has come to be regarded as one of the dynamically developing sectors of tourism, which has also become by now an important tool for local economic development (Scorrano et al., 2018).

As a result, researchers have also paid increasing attention to this area, one of the first steps of which was the creation of a definition taking all factors into account. According to Johnson et al. (2000), wine tourism can be defined as visits to vineyards, wineries, wine festivals and wine shows for the purposes of wine tasting and/or exploring a wine region, while in the opinion of Getz, who approaches this topic rather from the perspective of marketing, it is "travel related 
to the appeal of wineries and wine country, a form of niche marketing and destination development, and an opportunity for direct sales and marketing on the part of the wine industry" (Getz, 2000: 4).

Its uniqueness within tourism is due to the close relationship between natural and social factors. On the one hand, its development requires suitable natural conditions (good quality soil, favourable terrain and climate) (Gergaud and Ginsburgh, 2018), and thus to some extent it resembles beach and mountain tourism. On the other hand, in case these conditions are satisfied, the steps generally required for highly developed beach and mountain tourism (e.g. the construction of hotels and restaurants) are not sufficient, but some conscious/special steps by the stakeholders (the production of grapes and wines) are also necessary in order to create a product that is truly attractive to tourists.

In recent years, studies on wine tourism have focused on a variety of topics (Gómez et al., 2019), which are naturally also related to each other up to a certain extent. Papers in the first group emphasised the role of wine tourism in regional development, which included direct and indirect job creation (Gál-Czékus and Nagy-Kovács, 2017; Jurinčić and Bojnec, 2009), the benefits of creating wine routes (Del Chiappa et al., 2019; Trišić et al., 2020), as well as the issue of incomes generated locally (Byrd et al., 2016; Lipták, 2019). Research projects belonging to the second group focused on wine tourists. In this context, they explored their most important economic and social traits (Alonso et al., 2007), the factors that play a crucial role in participating in wine tourism, the expectations toward wine tourism (Grybovych et al., 2013, Kóródi et al., 2020) and the experiences it has generated, which also largely determines satisfaction (Gu et al., 2020; Pelegrin-Borondo et al., 2020).

Thirdly, in line with research on the topic of cultural tourism, a large number of researchers have also dealt with the issue of wine-related events (e.g. wine festivals). In the framework of the above, they have pointed out that in order to meet the needs of tourists, a complex package is required (Fusté-Forné, 2019; López-Guzmán, 2019), which includes, in addition to the presentation of region's wine offering, also the organisation of gastronomic type events (Carvache-Franco et al., 2020; Komariah et al., 2020). The fourth major topic concerns wine tourism and sustainability (Andrade-Suárez and Caamaño-Franco, 2020; Baird et al., 2018; Karagiannis and Metaxas, 2020), in which researchers draw attention to two things: they emphasise the need to use environmentally friendly technologies in the production of grapes, and to minimise the damage to nature through the environmental loads caused by tourists. In order to achieve the desired effects, research papers have underlined the importance of preliminary studies and the measurement of the impact of each risk factor.

\section{MATERIALS AND METHODS}

In the preparation of this paper, we have relied on a variety of sources of information. Firstly, we have reviewed the specialist literature on the region (Luda - Váradi, 2016; Nyizsalovszky, 2006; Törökné Kiss, 2014), as well as the strategies and concepts summarising the development ideas in order to explore the role of wine in the history of region and the current relationship of local governments to this feature. Secondly, we have analysed the data available on the website containing the results of the European Union grant applications submitted by various economic enterprises in the wine region (palyazat.gov.hu) to. Thirdly, we have also conducted personal interviews with the leaders of some of the major wineries in the region, in the course of which we have obtained inf ormation about the history and current situation of the wine region as well as their efforts to increase the satisfaction level of tourists.

\section{RESULTS AND DISCUSSION}

The history of the Tokaj Wine Region

Relying on the favourable natural conditions of the region (the loess layer of sever metres thickness on the volcanic andesite base rock, the erubase soil formed on the glacial till soil, the balanced temperatures, the dry and sunny weather in the autumn months, and the relatively constant humidity generated by the evaporation from the main watercourses of the area, the Bodrog and Tisza rivers - Nyizsalovszky, 2006), viniculture started in this area as early as the $9-10^{\text {th }}$ centuries. The Mongol invasion in the $13^{\text {th }}$ century destroyed almost $100 \%$ of the existing plantations, and in the interest of replanting them, King Béla IV invited Italian settlers to the region (their presence is witnessed by several settlement names such as Olaszliszka and Bodrogolaszi). They brought with them the most important grape varieties of their homeland (e.g. one of its most prominent grape varieties, Furmint, is of Italian origin), and they created the foundations of world famous wine region.

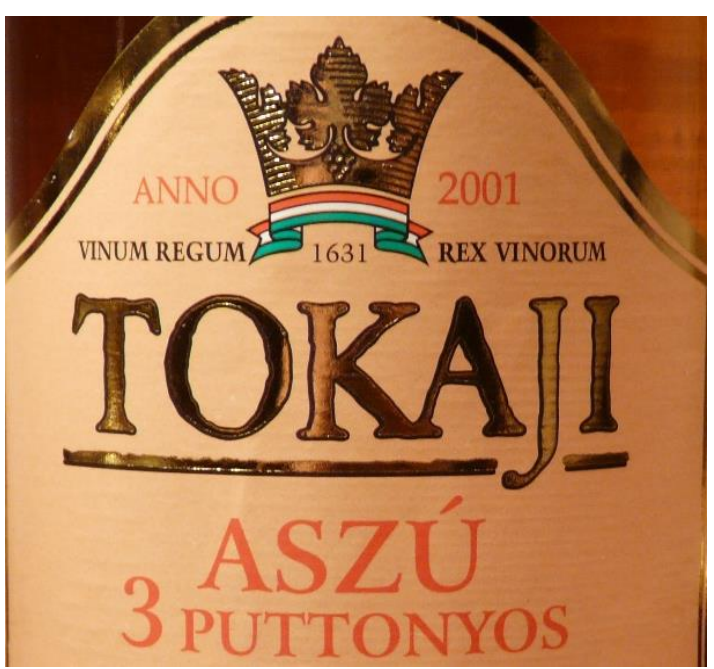

Figure 2. Famous sentence of King Louis XIV of France on a wine label of Tokaji Aszú (Source: own photo)

At the same time, in the first half of the Middle Ages, Hungary's most important wine region was Syrmia, located between the Drava and the Danube Rivers in present-day Croatia and Serbia, but the occupation of this area by the Ottoman Empire in the $16^{\text {th }}$ century opened the way for the rise of the Tokaj Wine Region (Törökné Kiss, 2014). From the $17^{\text {th }}$ century onwards, the most important product of the wine region has become Tokaji Aszú, which is made from grapes harvested late (mainly November), and the exquisite quality of which is due to the presence of the Botrytis cinerea fungus, causing the shrinking and rotting of the grapes. The outstanding importance of Aszú is reflected by the fact that the King Louis XIV of France called it "The Wine of Kings and the King of Wines" (Vinum regum, rex vinorum - Figure 2), while the Tsar Peter I and Tzarina Catherine I of Russia considered ensuring its trade so important that a detachment was stationed in Tokaj, which also supervised the acquisition and safety of the shipment (Wachtler - Nagy-Kovács, 2006). In order to ensure the quality of grape production, a royal decree was issued in 1737, the first of its kind in the world, to declare Tokaj as a closed wine region, pursuant to which the production has continued for the past almost 300 years in a strictly regulated way (Szepesi et al., 2016). In the second half of the $19^{\text {th }}$ century, the phylloxera epidemic appearing in Hungary also caused considerable destruction in the vineyards of the Tokaj wine region (Incze and Novák, 2016). When replanting began in the early $20^{\text {th }}$ century, the steeper, less accessible parcels were allowed to go fallow, and more of the foothill areas that were less steep and therefore easier to cultivate, but had overall less favourable properties from the perspective of grape quality, were brought under cultivation instead. Between the two world wars, the government paid less attention to the development of the region, and thus the export of wine decreased significantly. After World War II, due to the priority placed on industrial development, agriculture (including viticulture and viniculture) was pushed into the background. In line with the spirit of the age, a quantitative approach became dominant, and the main target of sales was the Comecon countries.

Winemaking in Tokaj became almost exclusively the task of the Tokaj-Hegyalja State Winery, established in 1971. Thus, almost all of the wine supply of the region was concentrated in a single hand, resulting in the loss of diversity in the variety of vineyards. Generally, 
medium to low-quality wines were produced, but certain high-quality wine specialities were also delivered to Western European markets. From the point of view of grape production, the fact that the planting of vines took place on the foothills with an inclination of 1-2\% only, bringing these parcels into cultivation allowed the use of agricultural machinery, but resulted in a deterioration in quality. Wine tourism, which started in the 1970s and 80s, was primarily the privilege of large wineries under the control of the State Winery, while small producers were first allowed to organize wine tastings from the 1980s only. Both in case of state wineries and small producers, according to the wine law in effect at the time, wine tourists could taste the standard wine offering, which included dry Furmint, semi-dry Hárslevelü, dry Szamorodni, sweet Szamorodni, as well as Aszú (the principal attraction, however, was clearly the tasting of the Aszú and Szamorodni varieties).

\section{Changes in Tokaj Wine Region over the past 30 years}

Since the 1990s, significant changes have taken place in the Tokaj Wine Region, which have also affected the region's wine tourism. On the one hand, a major change in ownership has taken place: as a result of the privatisation, the State Winery, which had previously played an almost monopolistic role, was broken up, giving way to thousands of small wineries. As the legal successor of the State Winery, the private company Tokaj Kereskedőház Rt. was founded in 1993, which is engaged in viticulture, viniculture and wine trade, and is considered one of the largest purchasers of grapes. In addition, for various reasons (e.g. the special reputation of the area), foreign investors also show increasing interest in the region in the 1990s. Among those foreign investors, the English appeared first, who founded Royal Tokaji Wine Co. in Mád. French investors bought property in Bodrogkeresztúr and Sárospatak (Chateau Dereszla Bodrogkeresztúr and Chateau Pajzos-Megyer Sárospatak-Tolcsva). In Mezőzombor, the Disznókö Vineyard belongs to the French AXA Millésimes, the Degenfeld Winery is owned by a German-Hungarian (Mária Degenfeld - Thomas Lindner) family, while the Tokaj Oremus winery in Tolcsva is in the hands of the Spanish Alvarez family. In Tarcal, Királyudvar winery is owned by Anthony Hwang, a Far Eastern investor.

The second most important factor was the evolution in the technology of winemaking (Tóth, 2016). Before the 1990s, it was typically the oxidative process that was used in the region, as a result of which, during the long ageing period, a symbiosis emerged between the noble rot in the cellar and the wine aged in the barrels (the materials produced by the noble rot in the microclimate of the cellar find their way into the wine during the extraction periods). This method has served as the basis of the high quality of Tokaji Aszú, and because of its high content of penicillin, it is not a coincidence that the real Aszú was also once sold in pharmacies. At the same time, the disadvantage of the method was the high evaporation loss associated with long ageing and the significant labour demand (more extractions per year). As a result - in line with the foreign investor's demand for profits - the so-called "reductive" process has become more widespread after 1990, in which wines are aged in steel containers with the exclusion of oxidation, thus reducing the ageing times and preserving the primary fragrance and flavour materials in the wine. Based on the in-depth interviews conducted in the framework of the research project and first-hand experiences gained on site, it has been shown that the reductive process is used in 75 to $80 \%$ of the wineries examined, and they contribute to an increase of the number of wines available for tasting (in addition, so-called "combined" wines, in which the two methods are combined, have also appeared).

Thirdly, the development of the region has

Table 1. The most important data of the subsidies received in the Tokaj wine region in the framework of the

"VP-4.2.2-16 Supporting the product development and resource efficiency of wineries" and the "VP-4.1,3-16 Modernisation of horticulture - Procurement of horticultural machinery" aid schemes between 2014 and 2020 in a breakdown according to settlements (Data source: own calculation based on palyazat.gov.hu)

\begin{tabular}{|l|c|c|c|c|}
\hline & \multicolumn{2}{|c|}{ VP-4.2.2-16 aid scheme } & \multicolumn{2}{c|}{ VP-4.1.3-16 aid scheme } \\
\hline & $\begin{array}{c}\text { number of } \\
\text { application } \\
\text { supported (pieces) }\end{array}$ & $\begin{array}{c}\text { amount of } \\
\text { grant awarded } \\
\text { (million HUF) }\end{array}$ & $\begin{array}{c}\text { number of } \\
\text { application } \\
\text { supported (pieces) }\end{array}$ & $\begin{array}{c}\text { amount of } \\
\text { grant awarded } \\
\text { (million HUF) }\end{array}$ \\
\hline Abaújszántó & 2 & 35.1 & 3 & 17.4 \\
\hline Bekecs & - & - & 2 & 14.0 \\
\hline Bodrogkeresztúr & 5 & 189.2 & 3 & 27.8 \\
\hline Bodrogkisfalud & 4 & 222.6 & 4 & 25.4 \\
\hline Bodrogolaszi & - & - & - & - \\
\hline Erdőbénye & 6 & 92.4 & 3 & 12.3 \\
\hline Erdőhorváti & - & - & - & - \\
\hline Golop & - & - & - & - \\
\hline Hercegkút & 3 & 148.1 & 8 & 50.0 \\
\hline Legyesbénye & - & - & - & - \\
\hline Mád & 8 & 676.8 & 11 & 84.2 \\
\hline Makkoshotyka & - & - & - & - \\
\hline Mezözombor & 1 & 26.3 & 1 & 6.5 \\
\hline Monok & - & - & - & - \\
\hline Olaszliszka & 2 & 39.1 & 6 & 38.5 \\
\hline Rátka & 1 & 37.2 & 3 & 18.8 \\
\hline Sárazsadány & - & - & - & - \\
\hline Sárospatak & 7 & 360.0 & 5 & 32.0 \\
\hline Sátoraljaújhely & 4 & 285.5 & 5 & 26.7 \\
\hline Szegi & - & - & - & - \\
\hline Szegilong & - & - & 1 & 3.3 \\
\hline Szerencs & 2 & 63.2 & 11 & 74.6 \\
\hline Tarcal & 7 & 374.9 & 6 & 45.8 \\
\hline Tállya & 10 & 610.3 & 6 & 35.8 \\
\hline Tokaj & 5 & 433.0 & 3 & 22.3 \\
\hline Tolcsva & 6 & 314.9 & 10 & 51.9 \\
\hline Vámosújfalu & - & - & - & - \\
\hline Alltogether & 73 & 3908.7 & 91 & 587.7 \\
\hline & & & & \\
\hline
\end{tabular}
also been significantly influenced by the actions taken by the various state and local authorities. In the former group, the passing of new legislation, particularly Act CXXI of 1997 on viticulture and viniculture, as well as Government Decree $485 / 2016$ (XII. 28.) on the world heritage management plan of the Tokaj Wine Region Historic Cultural Landscape, should be mentioned. The above act reinforced the closed nature of the Tokaj wine region, listed the most important wines typical in the region, and also recorded their method of production, while the government decree defined the areas with the World Heritage site title, detailed the most important values of the region, as well as the methods of managing them. The most important of the local actions is the activity of the Tokaj Council of Wine Communities, established by the communities of the wine region, which includes, among other things, the coordination and professional review of the organisation of the rules of procedure of the individual wine communities, the organisation of cooperation between members, to facilitate their access to the market, and the protection of origin and quality.Fourthly, in contrast with the processes in the previous period, after 1990, vine cultivation was reduced on the peripheral foothills, and the steeper areas, previously allowed to go fallow or grown over by forests were brought under cultivation again (this aim was also served by the fact that no government aid was granted for planting vines in parcels at lower elevations).

This enabled the production of better quality grapes and, at the same time, the specific locations of vine production (vineyard parcel names) have become increasingly important for the differentiation of wines. The fifth important change is the increase in the number of vine varieties produced. The grape varieties Furmint (having a share of 60-65\%) and Hárslevelü (approximately 25-30\%), which had played a prominent role for a long time, remained important, but besides them, newer varieties of grapes (e.g. Zeta, Kabar, and Grasa de Cotnari) have also gained importance both in large wineries and in smaller ones, 
resulting in an expansion of the offering (Luda - Váradi, 2016). The last important factor is EU funding, which came to the region in the period 2014-2020 under the Rural Development Operational Programme. The most significant aid schemes for viticulture and viniculture were "VP4.2.2-16 Supporting the product development and resource efficiency of wineries" and "VP-4.1.3-16 Modernisation of horticulture Procurement of horticultural machinery," both financed by the European Agricultural and Rural Development Fund. The examination of the territorial distribution of the aids allows us to draw two important conclusions (Table 1). On the one hand, the majority of the settlements in the region (18 out of 27 settlements) benefited from some support of aim, which reflects the importance of viticulture and viniculture.

The settlements left out were either those with low populations (e.g. Sárazsadány - 299 inhabitants, Szegi - 268 inhabitants) or located on the edge of the wine region (e.g. Legyesbénye, Vámosújfalu), further away from the mountains, where natural conditions were not so favourable. On the other hand, it can be concluded that the majority of the subsidies has been granted to the western and south-western part of the wine region (e.g. Mád, Tarcal, Tállya, Tokaj), which is due to the greater popularity of these settlements, also linked to their more favourable geographical location. As a result of the factors discussed above, the number of wineries in the Tokaj Wine Region that also offer wine tastings has increased significantly in recent years, and there are currently 21 settlements in the region offering such a service (Figure 3 ). In terms of territorial distribution, the prominent role of settlements in the western - south-western part of the region can also be observed.

In the section dealing with the history of the Tokaj Wine Region, I mentioned that the range of wines offered for tasting by various wineries in the pre-1990 period was rather narrow, and consisted only of Aszú, Szamorodni, Hárslevelủ and Furmint.

The changes in the boundary conditions, as outlined above, have also brought about a significant transformation in this respect. The results of the survey among wineries (Table 2) show that, in addition to standard products, an increasing number of wineries are striving to expand their range with new wines and to increase their attractiveness by producing local specialities for tourists visiting the region. Wine routes, established in the 2000s, are designed to take advantage of the opportunities offered by tourism related to wines, as they combine wineries producing wines, restaurants offering local specialties, high-quality accommodations, tourist service providers, and attractions in the wine region. Today, there are four wine routes (Figure 4) named after different grape varieties, which include all but two villages in the wine region.

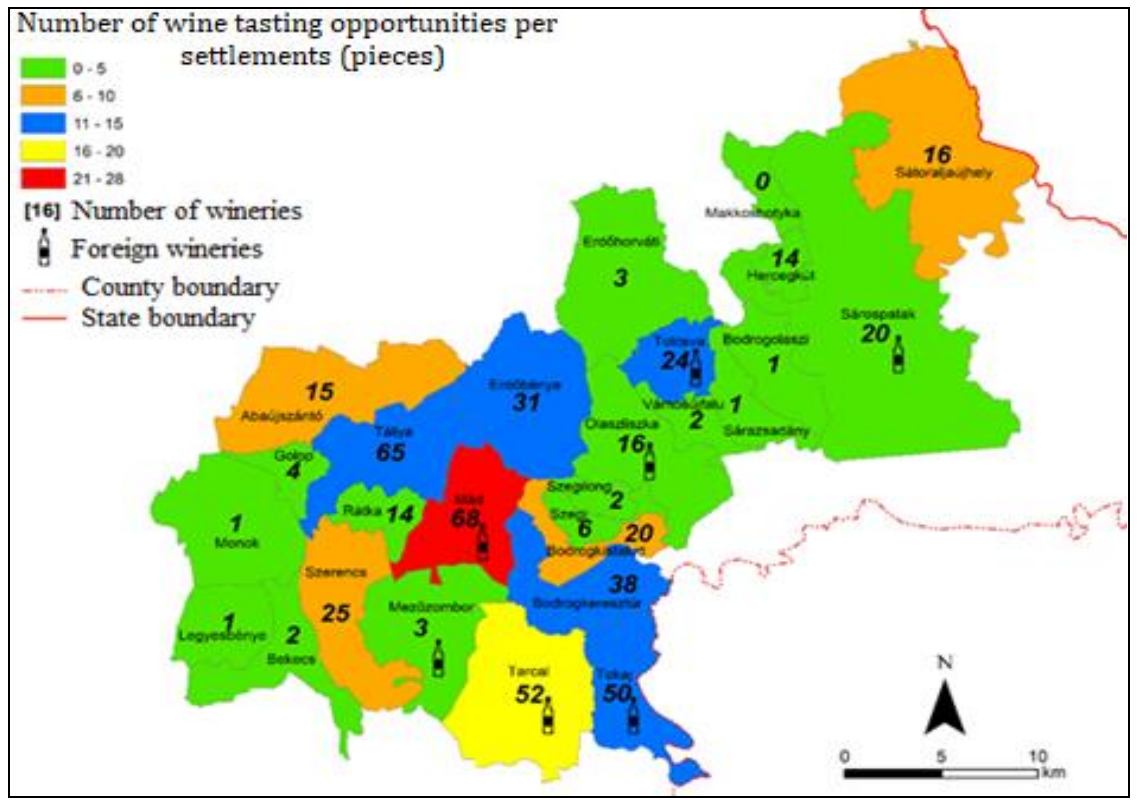

Figure 3. The number of wineries offering wine tasting on the individual municipalities of the Tokaj wine region (Source: own data collection)

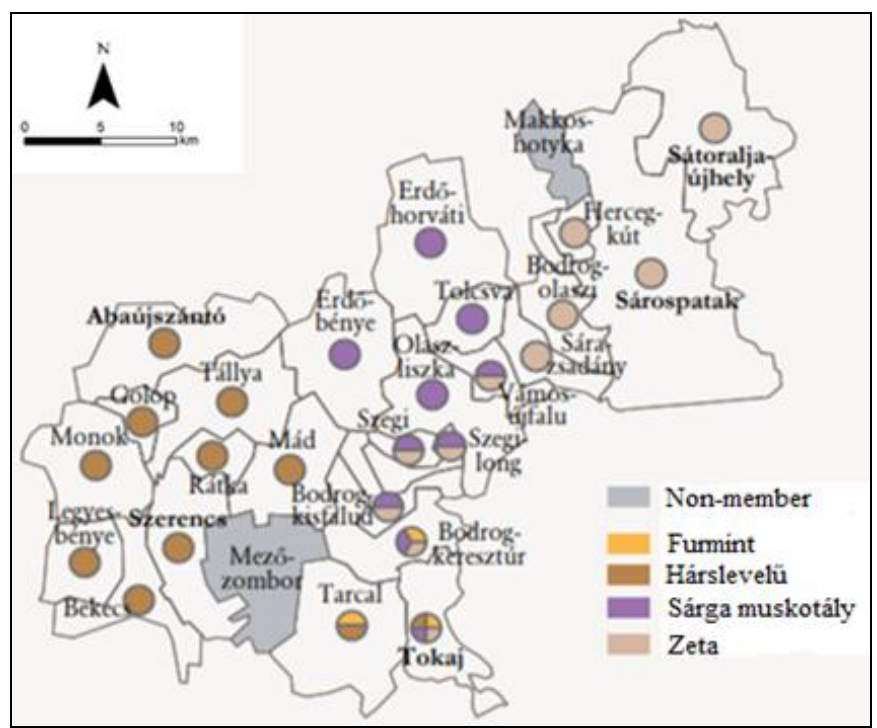

Figure 4. Wine routes in Tokaj Wine Region (Source: Central Statistical Office, 2016:11)
Table 2. Wines offered in the wine tastings of the most important wineries 1 - Aszú, 2 - Furmint, 3 - Szamorodni, 4 - Hárslevelü, 5 - Sárgamuskotály, 6-Cuvée, 7 -Zeta, 8 - Kabar, 9 - Grasa de Cotnari (Source: own data collection)

\begin{tabular}{|c|c|c|c|c|c|c|c|c|c|}
\hline & 1 & 2 & 3 & 4 & 5 & 6 & 7 & 8 & 9 \\
\hline Hímes winery (Tokaj) & $\mathrm{x}$ & $\mathrm{x}$ & $\mathrm{x}$ & & $\mathrm{x}$ & $\mathrm{x}$ & $\mathrm{x}$ & & \\
\hline Füleky winery (Bodrogkeresztúr) & $\mathrm{x}$ & $\mathrm{x}$ & & & $\mathrm{x}$ & & & $\mathrm{x}$ & \\
\hline Homoky winery (Tállya) & $\mathrm{x}$ & $\mathrm{x}$ & $\mathrm{x}$ & $\mathrm{x}$ & $\mathrm{x}$ & & & & \\
\hline Tokaj Classis (Mád) & $\mathrm{x}$ & $\mathrm{x}$ & & & $\mathrm{x}$ & $\mathrm{x}$ & & & \\
\hline Péter winery (Tokaj) & $\mathrm{x}$ & $\mathrm{x}$ & $\mathrm{x}$ & $\mathrm{x}$ & $\mathrm{x}$ & & $\mathrm{x}$ & $\mathrm{x}$ & $\mathrm{x}$ \\
\hline Erdős winery (Tokaj) & $\mathrm{x}$ & $\mathrm{x}$ & $\mathrm{x}$ & $\mathrm{x}$ & $\mathrm{x}$ & & & & \\
\hline Majoros winery (Tarcal) & $\mathrm{x}$ & $\mathrm{x}$ & $\mathrm{x}$ & $\mathrm{x}$ & $\mathrm{x}$ & $\mathrm{x}$ & & & \\
\hline Dereszla winery (Bodrogkeresztúr) & $\mathrm{x}$ & $\mathrm{x}$ & $\mathrm{x}$ & & $\mathrm{x}$ & & & $\mathrm{x}$ & \\
\hline Paulay winery (Tokaj) & $\mathrm{x}$ & $\mathrm{x}$ & $\mathrm{x}$ & $\mathrm{x}$ & $\mathrm{x}$ & $\mathrm{x}$ & & & $\mathrm{x}$ \\
\hline Simkó winery (Sárospatak) & $\mathrm{x}$ & $\mathrm{x}$ & & $\mathrm{x}$ & $\mathrm{X}$ & $\mathrm{x}$ & & & \\
\hline Tokaj Portius Sárospatak) & & $\mathrm{x}$ & $\mathrm{x}$ & & $\mathrm{x}$ & & $\mathrm{x}$ & & \\
\hline Barta winery (Mád) & $\mathrm{x}$ & $\mathrm{x}$ & $\mathrm{x}$ & $\mathrm{x}$ & $\mathrm{x}$ & & & & \\
\hline Götz winery (Hercegkút) & $\mathrm{x}$ & $\mathrm{x}$ & $\mathrm{x}$ & & $\mathrm{x}$ & $\mathrm{x}$ & & & \\
\hline Csubák winery (Tolcsva) & $\mathrm{x}$ & $\mathrm{x}$ & $\mathrm{x}$ & $\mathrm{x}$ & $\mathrm{x}$ & $\mathrm{x}$ & & & \\
\hline Zsirai winery (Mád) & $\mathrm{x}$ & $\mathrm{x}$ & $\mathrm{x}$ & $\mathrm{x}$ & $\mathrm{x}$ & $\mathrm{x}$ & & & \\
\hline Tokaj winery (Tokaj) & $\mathrm{x}$ & $\mathrm{x}$ & $\mathrm{x}$ & $\mathrm{x}$ & $\mathrm{x}$ & $\mathrm{x}$ & & & $\mathrm{X}$ \\
\hline Basilicius winery (Tarcal) & $\mathrm{x}$ & $\mathrm{x}$ & $\mathrm{x}$ & $\mathrm{x}$ & $\mathrm{x}$ & $\mathrm{x}$ & $\mathrm{x}$ & $\mathrm{x}$ & $\mathrm{X}$ \\
\hline Puklus winery (Bodrogkeresztúr) & $\mathrm{x}$ & $\mathrm{x}$ & $\mathrm{x}$ & $\mathrm{x}$ & $\mathrm{x}$ & $\mathrm{x}$ & $\mathrm{x}$ & $\mathrm{x}$ & $\mathrm{X}$ \\
\hline Angyal winery (Rátka) & $\mathrm{x}$ & $\mathrm{x}$ & $\mathrm{x}$ & $\mathrm{x}$ & $\mathrm{x}$ & $\mathrm{x}$ & & & \\
\hline Illés winery (Erdőbénye) & $\mathrm{X}$ & $\mathrm{x}$ & $\mathrm{x}$ & $\mathrm{x}$ & $\mathrm{X}$ & $\mathrm{x}$ & & & $\mathrm{x}$ \\
\hline Úri Borok winery (Mád) & $\mathrm{x}$ & $\mathrm{x}$ & $\mathrm{X}$ & $\mathrm{x}$ & $\mathrm{x}$ & & & & \\
\hline
\end{tabular}

Wine tourism and gastronomic events that strengthen the direct marketing part and enrich the experience of wine tourists with traditional and other cultural tourism experiences aim to increase the sense of satisfaction. Harvest parties are currently held in $80 \%$ of the settlements of the Tokaj wine region, but in themselves they are not attractive to tourists. Bor Mámor Bénye, Mádi Furmint Ünnep, Kerekdomb Fesztivál Tállya, Tarcali Charmed Weekend and the Tokaj Harvest Days are the most important wine festivals in the region. At the same time, the main weakness of wine-related events is that they are not aimed at the target audience but at everyone, and as a result they cannot ensure the quality of wine.

\section{CONCLUSION}

The most important findings of the study could be summarised as follows. In the area of viticulture and viniculture, significant changes 
have taken place in the Tokaj Wine Region in the past 30 years. New economic operators have emerged as foreign investors appeared, and new opportunities have also opened up in wine-making technology. Grape cultivation started to return to the steeper areas used more extensively in the period before the $19^{\text {th }}$ century, and partly in a parallel way, the range of grape varieties produced has also broadened. Central and local regulations increasingly focused on quality grape production, and this was also supported by grant opportunities.

As a result of these processes, wine tourism in the region has also undergone significant changes. On the one hand, besides larger wineries, smaller producers have also opened towards this type of tourism, as indicated by the increase in the number of wine tasting opportunities. On the other hand, the range of wines offered at wine tastings has been continuously expanded: in addition to the previous standard offering (Aszú, Hárslevelü, Furmint, Szamorodni), the new wine varieties have started to play an increasingly import ant role.

At the same time, the geographical impact of these changes can be observed as well: in contrast to the eastern regions, settlements on the western side of the wine region are becoming increasingly important (e.g. Mád, Tállya). However, the impact of a number of factors should be taken into account in the future of the wine region. Overall, we can conclude that tourists have welcomed the changes taking place, the improvement of quality and the widening of the product range. At the same time, I also consider it important that the new flavours, the more economical technologies should not displace the Aszú production technology with its centuries-old traditions, which remains one of the main image elements of the region (Béres-Virág and Ritter, 2018; Kozma and Czimre, 2014). International experience proves that a unique product that defines the image of the region cannot be forgotten because the tourist attraction of the area is impaired. In the future, it is also important that the wine that has made Tokaj-Hegyalja world famous should be a stable and main element of the wine supply.

\section{REFERENCES}

Alonso, A., Fraser, R.A., \& Cohen, D.A. (2007). Investigating differences between domestic and international winery visitors in New Zealand. International Journal of Wine Business Research, 19(2), 114-126. https://doi.org/10.1108/17511060710758678

Andrade-Suárez, M., \& Caamaño-Franco, I. (2020). The Relationship between Industrial Heritage, Wine Tourism, and Sustainability: A Case of Local Community Perspective. Sustainability, 12(18), 7453. https://doi.org/10.3390/su12187453

Baird, T., Hall, C.M., \& Castka, P. (2018). New Zealand winegrowers attitudes and behaviours towards wine tourism and sustainable winegrowing. Sustainability, 10(3), 797. https://doi.org/10.3390/su10030797

Béres-Virág, Á., \& Ritter, K. (2018). Tourist evaluation of Tokaj Wine Region. Studia Mundi-Economica, 5(2), 74-86.

Byrd, E.T., Canziani, B., Hsieh, Y.C.J., Debbage, K., \& Sonmez, S. (2016). Wine tourism: Motivating visitors through core and supplementary services. Tourism Management, 52, 19-29. https://doi.org/10.1016/i.tourman.2015.06.009

Carvache-Franco, M., Carvache-Franco, O., Carvache-Franco, W., \& Villagómez-Buele, C. (2020). Relationship between sociodemographic aspects, satisfaction and loyalty in gastronomic festivals. GeoJournal of Tourism and Geosites, 32(4), 1324-1329. https://doi.org/10.30892/gtg.32420-576

Central Statistical Office (2016). A világörökség részét képezö Tokaji borvidék [Tokaj Wine Region as part of UNESCO Word Heritage]. Central Statistacal Office, Budapest (in Hungarian).

Del Chiappa, G., Bregoli, I., \& Kim, A.K. (2019). Inter-sectorial collaboration in networks: A boundary object approach to wine routes. Tourism Planning \& Development, 16(6), 591-611. https://doi.org/10.1080/21568316.2018.1543727

Fusté-Forné, F. (2019). Travelling to municipal markets: an approach to cheese on offer. DETUROPE - The Central European Journal of regional Development and Tourism, 11(2), 22-29.

Gál-Czékus, I., \& Nagy-Kovács, E. (2017). The multiplying effect of wine tourism. In Thinking Together The economv in practice, 91-98, University of Obuda, Budapest.

Gergaud, O., \& Ginsburgh, V. (2018). Natural endowments, production technologies and the quality of wines in Bordeaux. Does terroir matter? In Handbook of the Economics of Wine, 2 (97), World Scientific Publishing Company.

Grybovych, O., Lankford, J., \& Lankford, S. (2013). Motivations of wine travelers in rural Northeast Iowa. International Journal of Wine Business Research, 25(4), 285-309. https://doi.org/10.1108/IJWBR-07-2012-0023

Gu, Q., Qiu, H., King, B.E., \& Huang, S. (2020). Understanding the wine tourism experience: The roles of facilitators, constraints, and involvement. Journal of Vacation Marketing, 26(2), 211-229. https://doi.org/10.1177/1356766719880253

Hlédik, E., \& Harsányi, D. (2019). Wine tourism in Hungary - wine and destination preferences of wine tour participants. In 18th International Congress of the International Association on Public and Nonprofit Marketing, Conference Proceeding, 45-57, University of Györ, Győr.

Getz, D. (2000). Explore wine tourism: Management, development \& destinations. Cognizant Communication Corporation, New York.

Gómez, M., Pratt, M.A., \& Molina, A. (2019). Wine tourism research: a systematic review of 20 vintages from 1995 to 2014 . Current Issues in Tourism, 22(18), 2211-2249. https://doi.org/10.1080/13683500.2018.1441267

Johnson, G., Cambourne, B., Hall, C.M., Sharples, L., Mitchell, R., \& Macionis N. (2000). Wine tourism: an introduction. In Wine Tourism Around the World: Development, Management and Markets, 1-23, Routledge, London.

Incze, J., \& Novák, T.J. (2016). Identification of extent, topographic characteristics and land abandonment process of vineyard terraces in the Tokaj-Hegyalja wine region between 1784 and 2010. Journal of Maps, 12(sup1), 507-513. https://doi.org/10.1080/17445647.2016.1195295

Jurinčić, I., \& Boinec, Š. (2009). Wine tourism development: the case of the wine district in Slovenia. Turizam: međunarodni znanstveno-stručni časopis, 57(4), 435-448.

Karagiannis, D., \& Metaxas, T. (2020). Sustainable Wine Tourism Development: Case Studies from the Greek Region of Peloponnese. Sustainability, 12(12), 5223. https://doi.org/10.3390/su12125223

Komariah, K., Razzaq, A.R.B.A., Nugraheni, M., Lastariwati, B., \& Mahfud, F. (2020). The antecedent factor of tourists' intention to consume traditional food. GeoJournal of Tourism and Geosites, 32(4), 1209-1215. https://doi.org/10.30892/gtg.32403-559

Kóródi, M., Mondok, A., Dávid, L.D., \& Szabó, A. (2020). Motivations and experiences concepts in the travel decisions of domestic tourists of the "Hungarian Great Plain". GeoJournal of Tourism and Geosites, 32(4), 1347-1354. https://doi.org/10.30892/gtg.32423-579

Kozma, G., \& Czimre, K. (2014). Role of historical elements in the slogans and logos used by Hungarian places in tourism promotion. In Enhancing competitiveness of V4 historic cities to develop toursim - Aspects of cultural heritage, 63-75, Krakow - Debrecen.

Lipták, K. (2019). The importance of social innovations in rural areas. DETUROPE - The Central European Journal of regional Development and Tourism, 11(3), 160-174.

López-Guzmán, T., Pérez-Gálvez, J.C., \& Muñoz-Fernández, G.A. (2019). A quality-of-life perspective of tourists in traditional wine festivals: The case of the wine-tasting festival in Córdoba, Spain. In Best Practices in Hospitality and Tourism Marketing and Management, 297-311, Springer, Cham.

Luda, Sz., \& Váradi, Zs. (2016). A Tokaji borvidék helyzetértékelése [Market-analysis of Tokaj Wine Region]. Tokaji Borvidék Fejlődéséért Nonprofit Kft., Budapest (in Hungarian).

Nyizsalovszki, R. (2006). Morfológia és területhasználat kapcsolata Tokaj-Hegyalján [Relationship between geomorphology and land use in Tokaj Wine Region] In Egy szakmai életút eredményei és színhelyei. Tiszteletkötet Martonné Dr. Erdös Katalin 60. Születésnapjára, 89-105, Debrecen, Hungary (in Hungarian).

Pelegrin-Borondo, J., Olarte-Pascual, C., \& Oruezabala, G. (2020). Wine tourism and purchase intention: a measure of emotions according to the PANAS scale. Journal of Wine Research, 31(2), 101-123. https://doi.org/10.1080/09571264.2020.1780573

Scorrano, P., Fait, M., Iaia, L., \& Rosato, P. (2018). The image attributes of a destination: an analysis of the wine tourists' perception. EuroMed Journal of Business, 13(3), 335-350. https://doi.org/10.1108/EMJB-11-2017-0045

Szepesi, J., Harangi, S., Ésik, Z., Novák, T.J., Lukács, R., \& Soós, I. (2017). Volcanic geoheritage and geotourism perspectives in Hungary: A case of an UNESCO world heritage site, Tokaj wine region historic cultural landscape, Hungary. Geoheritage, 9(3), 329-349.

Tóth, P. (2016). Rendszerváltó borászatok Magyarország szölöhegyein [Wineries in Hungarian wine regions]. Doctoral Dissartion, Budapest University of Technology and Economics, Budapest, Hungary (in Hungarian).

Törökné, Kiss K.Á. (2014). Tokaj-hegyalja borturizmusa [Wine tourism in Tokaj-Hegyalja]. Agrártudományi Közlemények, 55, 125-127, (In Hungarian).

Trišić. I., Štetić, S., Privitera, D., \& Nedelcu, A. (2020). Wine routes in Vojvodina province, Northern Serbia: A tool for sustainable tourism development. Sustainability, 12(1), 82. https://doi.org/10.3390/su12010082

Trišić, I., \& Nagy-Kovács, E. (2006). A Borturizmus az Észak-magyarországi Régióban [Wine tourism in North Hungarian Region]. Gazdálkodás, 15. (special edition), 70-81, (in Hungarian). 